\title{
Effect of Wind to the Maneuvering Ship Control in the Avoidence Collision
}

\author{
I G. A. N. Mahesa Pratama Putra ${ }^{1}$ and Aulia S. Aisjah ${ }^{2}$
}

\begin{abstract}
Marine transportation as an important roles in Indonesia, it is two third of Indonesian territorial is waters. Tanjung Perak port is one busiest transportation in Indonesia. To enter the terminal ship is shipping throuh Madura strait. To enhance ship safety management, navigational device known as AIS used for navigational purpose. AIS data contain multiple ship specification, statically and dynamically. Those data can be used as inputs in maneuvering control. This research focus on creating ship maneuvering control system by utilizing AIS data. The strategic control is Fuzzy Logic (FL). The aim of research is carrying ship to the trajectory to collision avoidence to other ship. The Fuzzy Logic Control consits two units: Heading control and speed control. The case study is applying controler to the cargo ship, and disturbance is wind in various coming angle.
\end{abstract}

\section{Keywords-AIS, Collision Avoidance, Fuzzy Logic Controller, Naval Transportation, Wind disturbance}

\begin{abstract}
Abstrak-Transportasi laut memegang peranan penting di Indonesia, karena dua pertiga dari wilayah Indonesia merupaka perairan. Kecelakaan kapal akibat kesalahan manusia maupun yang diakibatkan gangguan masih sering terjadi di Selat Madura sehingga dibutuhkan sistem pengendalian untuk mencegah tabrakan. Sistem pengendalian ini didesain untuk memanfaatkan masukan dari kompas, gyrocompass dan data AIS seperti koordinat dan kecepatan kapal. Terdapat 2 masukan untuk fuzzy manuver yaitu error yaw (e) dan yaw rate (r) dimana tiap masukan memiliki 7 fungsi keanggotaan. Fuzzi pengendali kecepatan memiliki 3 masukan yaitu : jarak dengan 2 fungsi keanggotaan, rasio kecepatan dengan 3 fungsi keanggotaan, dan delta $X$ dengan 3 fungsi keanggotaan. Penelitian ini dilakukan dengan menggunakan perangkat lunak simulasi dengan angin sebagai gangguan alam pada dinamika kapal. Hasil simulasi menunjukan saat sudut datang angin diasumsikan 30o, 90o,dan 150o. Sudut yaw kapal menyimpang berturut-turut sebesar $0.352^{\circ}, 0.334^{\circ}$, dan $0.171^{\circ}$.
\end{abstract}

Kata Kunci-AIS, Penghindaran Tabrakan, Kendali Logika Fuzzy, Transportasi laut, Gangguan Angin

\section{INTRODUCTION}

M arine transportation nowadays hold an important roles at intercontinental or interingular goods distribution system. Because of it's characteristic which can carry hundred or thousand ton of loads, marine transportation is preferably than air transportation although the distribution time is longer. The heavy burden of loads make marine transportation very hazardous at a narrow sea. Safety degree is lowered if there is more ships. Ship collision happened very often at Madura strait as a result of human error and nature disturbance such as wave, sea current, and wind. Between July 2004 and September 2011 there is 10 ship collision accident at Madura strait .

Since 2000 IMO (International Maritime Organization) standardized every ship to equipped with AIS (Automatic Identification System) to increase safety management at marine transportation. Operator at harbor can detect the ship characteristic that equipped with AIS such as its loads, type, coordinate (latitude and longitude), direction ,and etc by using AIS. In other hand, there are several drawback in AIS application such as: AIS used no more than 20

I G. A. N. Mahesa Pratama Putra and Aulia Siti Aisjah is with Departement of Engineering Physics, Faculty of Industrial Technology, Sepuluh Nopember Institute of Technology, Surabaya, Indonesia. Email: yagami_kun@ep.its.ac.id ${ }^{1}$, auliasa@ep.its.ac.id ${ }^{2}$ character, display error about ship dimension often occurred, misinformation of heading, course over ground (COG), Velocity over ground (SOG) and location of the ship, and AIS usually not compatible with other hardware / instrument [1]. From the data received from AIS combined with wind, sea current, and wave data, we can make a maneuvering and velocity recommendation for the sailor to avoid ship collision.

\section{METHOD}

Ship controlled in this research is LCT Bintang Samudra 2 and ship used as obstacle is LCT Bintang Samudra 1. Input data for fuzzy logic controller obtained from AIS data of respective ship. Data from AIS used as input for control system included latitude, longitude, and velocity. Latitude and longitude data from AIS will be converted into $\mathrm{x}, \mathrm{y}(\mathrm{m})$ coordinate using following equation.

$1^{o}=111322 \mathrm{~m}$

Fuzzy logic controller (FLC) used as controller for ship maneuvering and velocity. For maneuvering controller it use sugeno type fuzzy logic meanwhile for velocity controller it use mamdani type fuzzy logic. Input for maneuvering fuzzy are error yaw (e) and yaw rate (r) while the output is rudder command $\left(\delta_{R}\right)$. Error yaw is difference between actual yaw and desired yaw while yaw rate is differentiation of actual yaw.

Input for velocity fuzzy were DeltaX, distance, and velocity ratio between two ships (V2/V1). DeltaX is $\mathrm{x}$ coordinate difference between $\mathrm{x}$ actual $(\mathrm{Xa})$ and $\mathrm{x}$ desired (Xd). Distance is space between controlled ship and 
obstacle ship. Velocity ratio here is ratio between controlled ship and obstacle ship Distance between two ships obtained using equation below :

$$
d=\sqrt{\left(x_{1}-x_{0}\right)^{2}+\left(y_{1}-y_{0}\right)^{2}}
$$

Generaly, there is 2 ship movement in waters, translation and rotation. Ship translations move divided into 3, that is heave, surge, and sway. Ship rotation moves also divided into 3, that is yaw, roll, and pitch

Yaw move is ship spinning movement into side direction, heave is an upside move, roll is downside move, surge is ship forward movement, sway is ship side movement, and pitch is ship spinning movement to forward. Ship maneuvering control equation can be described as follows :

$\mathbf{M} v^{\prime}+\mathbf{D} v=\tau_{L}$

Where $v=[u, v, r]^{\mathrm{T}}$ are the speed vector that gonna be differentiated into 2 range frequency modeling form, which

is high frequency and low frequency, and $\tau_{L}$ was moment and and force control vector. $\mathbf{M}$ and $\mathbf{D}$ was inertia matrix and attenuation received from moment and force linearization of surge, sway, and yaw move.

Ship rudder system and speed control equation will be obtained with several assumption, which was :

a) Homogenous mass distribution and $\mathrm{xz}$ field was symmetrical $\left(I_{x y}=I_{y z}=0\right)$

b) Pitch, roll, and heave move ignorable $(\omega=\mathrm{p}=\mathrm{q}=0)$

Use mentioned assumption into equation :

Surge: $m\left(u-v r-X_{G} r^{2}\right)=X$

Sway: $m\left(v-u r-X_{G} r\right)=Y$

Yaw: $I_{z} r+m X_{G}(v+u r)=N$

Ship maneuver dynamic modeling processed using Nemoto approach (1957) as $2^{\text {nd }}$ order mathematical model. Transfer function from Nemoto model is as follows

$: \frac{\psi}{\delta_{R}}(s)=\frac{K_{R}\left(1+T_{3} s\right)}{s\left(1+T_{1} s\right)\left(1+T_{2} s\right)}$

Ship velocity model obtained from approach by Horigome, Hara, Hotta, and Hotsu (1940) as a $1^{\text {st }}$ order mathematical form. The ship velocity transfer function transfer function is as follows :

$$
\frac{Q_{m}}{Y}(s)=\frac{K_{y}}{1+T_{y} s}
$$

$K_{y}$ was the gain constant and $T_{y}$ was time constant.

Wind force model in surge and sway, then wind moment model in yaw based on Isherwood (1972) was :

$$
\begin{aligned}
& X_{\text {wind }}=\frac{1}{2} C_{x}\left(\gamma_{R}\right) \rho_{a} V_{R}^{2} A_{T}(\mathrm{~N}) \\
& Y_{\text {wind }}=\frac{1}{2} C_{x}\left(\gamma_{R}\right) \rho_{a} V_{R}^{2} A_{L}(\mathrm{~N}) \\
& N_{\text {wind }}=\frac{1}{2} C_{N}\left(\gamma_{R}\right) \rho_{a} V_{R}^{2} A_{L} L(\mathrm{Nm})
\end{aligned}
$$

Where $C_{X}$ and $C_{Y}$ are the force coefficient, $C_{N}$ is the moment coefficient, $\rho_{a}$ is the density of air $\left(\mathrm{Kg} / \mathrm{m}^{3}\right), V_{R}$ were wind velocity $(\mathrm{m} / \mathrm{s}), A_{T}$ and $A_{L}$ are the transverse and lateral projected areas in $\mathrm{m}^{2}$ and $\mathrm{L}$ is the overall length of the ship in $\mathrm{m}$. Keep in mind that $V_{R}$ is given in knots.

According Isherwood, $C_{X}, C_{Y}$, and $C_{N}$ can be obtained from the following equation :

$C_{X}=A_{0}+A_{1} \frac{2 A_{L}}{L^{2}}+A_{2} \frac{2 A_{T}}{B^{2}}+A_{3} \frac{L}{B}+A_{4} \frac{S}{L}+A_{5} \frac{C}{L}+A_{6} M(12)$
$C_{Y}=B_{0}+B_{1} \frac{2 A_{L}}{L^{2}}+B_{2} \frac{2 A_{T}}{B^{2}}+B_{3} \frac{L}{B}+B_{4} \frac{S}{L}+B_{5} \frac{C}{L}+B_{6} \frac{A_{s s}}{A_{L}}(13)$

$C_{N}=C_{0}+C_{1} \frac{2 A_{L}}{L^{2}}+C_{2} \frac{2 A_{T}}{B^{2}}+C_{3} \frac{L}{B}+C_{4} \frac{S}{L}+C_{5} \frac{C}{L}$

Wind disturbance changes ship sway moves, make it to stray from its original route. In this case surge and yaw moves doesn't give significant impact for ship maneuvering so it can ignorable. Thus transfer function for ship based on wind influence at sway moves can be defined as wind force model in sway divided by ships resistance. Ship resistance approached using det (M). Complete equation can be seen in equation below.

Wind Transfer Function $=\frac{Y_{\text {wind }}}{\text { Ship resistance }}$

\section{RESULTS AND DISCUSSION}

\section{A. Ship Transfer Function}

Ship Maneuver Dynamic modeling processed using Nemoto approach (1957) as a $2^{\text {nd }}$ order mathematical model. Transfer function from Nemoto model is as follows

$\frac{\psi}{\delta_{R}}(s)=\frac{K_{R}\left(1+T_{3} s\right)}{s\left(1+T_{1} s\right)\left(1+T_{2} s\right)}$

where ships specification data of LCT Bintang Samudra 2 acquired as follows:

$\begin{array}{ll}L_{p p} \text { (Length) } & : 50.4 \mathrm{~m} \\ \mathrm{U} \text { (Velocity) } & : 6 \text { knots } \\ \mathrm{B} \text { (Width) } & : 13.5 \mathrm{~m} \\ \mathrm{~T} \text { (Height) } & : 3.8 \mathrm{~m} \\ C_{B} \text { (Block Coefficient) } & : 0.6414 \\ \mathrm{XG} & : 2.39 \\ A \delta & : 0.69 \\ \mathrm{~m} \text { (displacement) } & : 1700 \text { Ton } \\ \mathrm{r} & : 7.56 \\ { }_{\mathrm{m}}, & : 0.0259 \\ \mathrm{XG} & : 0.1230 \\ \mathrm{DWT} & : 1100 \text { Ton }\end{array}$

Therefore, ship dynamic transfer function of LCT Bintang Samudra 2 is :

$$
\frac{\psi}{\delta_{R}}=\frac{1.109+13.171 s}{13.343 s^{3}+10.695 s^{2}+s}
$$

\section{B. Wind Disturbance Function}

Calculation of , $A_{\mathrm{L}}, A_{T}, A_{55}, \mathrm{~S}, \mathrm{C}$, and $\mathrm{M}$ based on LCT type shiplane.

$$
\begin{aligned}
& A_{L}=90+90.48=180.48 \mathrm{~m}^{2} \\
& A_{T}=78+20.28=98.28 \mathrm{~m}^{2} \\
& A_{s s}=30+60=90 \mathrm{~m}^{2} \\
& S=58.2+(7 \times 56 \times 2)=131 \mathrm{~m} \\
& C=\frac{58}{2}=29 \mathrm{~m} \\
& M=1
\end{aligned}
$$

Those eight parameter used in the calculation based on equation $(2.30-2.35)$ described as follow for incoming wind angle $30^{\circ}, 90^{\circ}$ and $150^{\circ}$ respectively.

Incoming wind angle $30^{\circ}$ 
$C_{Y}=0.672$

$Y_{\text {wind }}=\frac{1}{2} C_{Y}\left(\gamma_{R}\right) \rho_{w} V_{R}^{2} A_{L}=\frac{1}{2}(0.672)(1.224)(900)(180.48)=66802 \mathrm{~N}$

Wind Transfer function $30^{\circ}=\frac{Y_{\text {wind }}}{\operatorname{det}(M)}=\frac{258376}{189731.68}=0.352$

Incoming wind angle $90^{\circ}$

$C_{Y}=B_{0}+B_{1} \frac{2 A_{L}}{L^{2}}+B_{2} \frac{2 A_{T}}{B^{2}}+B_{3} \frac{L}{B}+B_{4} \frac{S}{L}+B_{5} \frac{C}{L}+B_{6} \frac{A_{s s}}{A_{L}}$

$C_{Y}=0.658$

$Y_{\text {wind }}=\frac{1}{2} C_{Y}\left(\gamma_{R}\right) \rho_{w} V_{R}^{2} A_{L}=\frac{1}{2}(0.658)(1.224)(900)(180.48)=65410 \mathrm{~N}$

Wind Transfer Function $90^{\circ}=\frac{Y_{\text {wind }}}{\operatorname{det}(M)}=\frac{252994}{189731.68}=0.334$

Incoming wind angle $150^{\circ}$

$C_{Y}=B_{0}+B_{1} \frac{2 A_{L}}{L^{2}}+B_{2} \frac{2 A_{T}}{B^{2}}+B_{3} \frac{L}{B}+B_{4} \frac{S}{L}+B_{5} \frac{C}{L}+B_{6} \frac{A_{s s}}{A_{L}}$

$C_{Y}=0.328$

$Y_{\text {wind }}=\frac{1}{2} C_{Y}\left(\gamma_{R}\right) \rho_{w} V_{R}^{2} A_{L}=\frac{1}{2}(0.328)(1.224)(900)(180.48)=32605 \mathrm{~N}$

Wind Transfer Function $150^{\circ}=\frac{Y_{\text {wind }}}{\operatorname{det}(M)}=\frac{126112}{189731.68}=0.171$

\section{C. $\quad$ Open Loop Test of LCT Bintang Samudra 2}

From the acquired transfer function, we will doing open loop diagram test to see response of the ships without a controller. Set point used in this open loop test is step signal to make it easier finding dynamic response of ship maneuver angle From this test it will be observed relation between ship maneuvering angle changes with time needed. Thus, the output from scope can be seen in figure 3 .

\section{D. $\quad$ Open Loop Test of LCT Bintang Samudra 2}

Closed loop test will be done based on ship dynamic model and maneuvering control block diagram. Input of the system is heading set point. Purpose of closed loop test is to see controller influence toward ship response. In this case there will be two kind treatment, heading $20^{\circ}$ and $30^{\circ}$. Reason why $20^{\circ}$ and $30^{\circ}$ used as set point heading based on IMO (International Maritime Organization) rules.

\section{E. Close Loop Test Without Ship Obstacle and Without Wind Distrubance}

In this sub chapter, we will try to test ship maneuvering and velocity control to track desired value. Test ships used as controllable ship was LCT Bintang Samudra 2 and there is no obstacle and disturbance. Route taken by controlled ships received from AIS data and plotted using simulation software can be seen in figure 6 .

From those plotted route, its decided that real route of LCT Bintang Samudra 2 wasn't good enough to used. As can be seen, that route have a lot of vortex and a little bit awkward. It can be assumed that LCT Bintang Samudra 2 at that moment does not not intended to sail from one port to another, but just hang around in the same port. Because real route of LCT Bintang Samudra 2 can't be used, so naval route from Tanjung Perak - Karang Jamuang will be used to replace it.

This route is permitted by Naval Navigation District Tanjung Perak Surabaya which usually used by ship to sail betwwen Tanjung Perak and Karang Jamuang. This route start at Tanjung Perak harbour (bottom right), then ship sail to the west then finally turn right head to Karang Jamuang (top right).

At point actual heading need 25 second to reached desired heading $-12^{\circ}$. At point $\mathrm{B}$ actual heading cannot reach desired heading at $16^{\circ}$ before it changed set point. At point $\mathrm{C}$ actual heading cannot keep up with desired heading which was same like at point $\mathrm{B}$ before. At point $\mathrm{D}$ actual heading need 20 second to reached desired heading. At point $\mathrm{E}, \mathrm{F}, \mathrm{G}$, and $\mathrm{H}$, actual heading relatively stable, which it can reached desired heading quite fast with no overshoots. At point I, J, and $\mathrm{K}$ turning angle from one point to another quite small, so actual heading not find any difficulties to reached desired heading.

\section{F. Close Loop Test With Ship Obstacle and Without Wind Distrubance}

Maneuvering fuzzy control and velocity fuzzy control will be tested to analyze it's performance if obstacle was given. Ship used as obstacle is LCT Bintang Samudra 1 which AIS data include latitude coordinate, longitude coordinate, and ships velocity.. Intersection response when LCT Bintang Samudra 1 route and LCT Bintang Samudra 2 route crossed each other can be seen in figure 9 .

Ship maneuvering response with ship obstacle can be seen in figure 8 . There is a little dissimilarity from ship maneuvering response without obstacle. At point $\mathrm{E}$ precisely at $t=114$, route from both of ships crossed each other. Because of that anti ship collision controller change ship heading from $\psi=-9^{\circ}$ into $\psi=5^{\circ}$ for 9 seconds before it change back to $\psi=-5^{\circ}$ at $\mathrm{t}=123$. Time here is simulation time from 0 to 318 second. Actual sailing time from Tanjung Perak to Karang Jamuang is approximately 3 hours normally. Intersection point between two ships happened at $\mathrm{t}=114 \mathrm{~s}$ in simulation time around 70 minutes in real time. Ship response at point $\mathrm{E}$ quite decent, where actual heading can react when desired heading set point suddenly changed because route from both of ships crossed. But because of new desired heading at point $\mathrm{E}$ have a short time span (9 seconds), actual heading cant reached desired set point at $9^{\circ}$ but it only reached $-1^{\circ}$ before desired heading back to normal. After ship intersection at point $\mathrm{E}$, there is no other intersection because both of ships sail in different direction.

\section{G. Close Loop Test With Ship Obstacle and With Wind Distrubance}

Wind disturbance here given in 3 assumption : incoming wind angle $30^{\circ}, 90^{\circ}, 150^{\circ}$. Overall there is no huge difference in ship response when wind disturbance given. Visible difference only at initial actual heading shifted a bit based on how much wind force is.

Overall wind disturbance does not have big impact for ship control system. $1-0.5$ displacement at heading, is not a serious problem for naval transportation. There is few reason why wind disturbance did not have big effect. First, wind disturbance relies heavily from average wind speed at those area. In this case area where the ship route was Madura strait. Average wind velocity at Madura strait usually not so high because it is located between two big islands (java and Madura), so wind force from java sea and Hindian ocean can not reach this area. Second ship used as controlled ship is LCT (Landing Craft Tank), this type of ship has narrow lateral and transversal area because of it designed so thin to reduce wind force aerodynamically. 


\section{H. Seasonal Wind Influence Toward Wind Disturbance Calculation}

Wind velocity in an open waters change as time goes on. It caused by the changes of temperature, pressure, air humidity, sun position and etc. So it is essential to include variety of wind type as consideration when wind disturbance toward ships heading calculated.

By classifying each type of wind type based its own speed, we can make complete data about wind disturbance effect toward yaw heading per type of wind. Wind velocity per description of wind assumed in its maximal value, in example when gentle breeze, wind speed assumed $11 \mathrm{knot}$ instead of 8 knot. Incoming wind angle also assumed $30^{\circ}$, $90^{\circ}$, and $150^{\circ}$ same like previous test.

\section{CONCLUSIONS}

From this research, there are several conclusion that can be taken as follows:

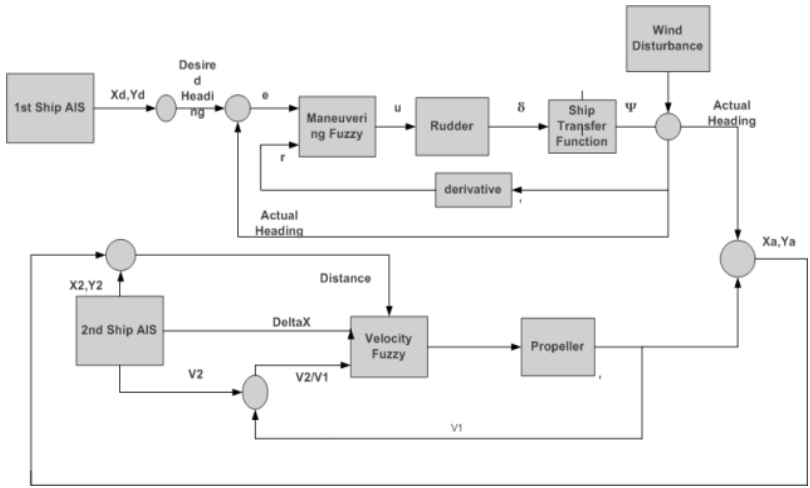

Figure 1. Control block diagram

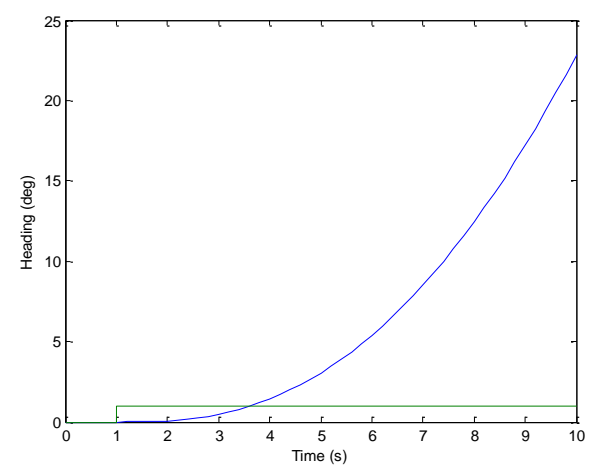

Figure 3. Open loop test response

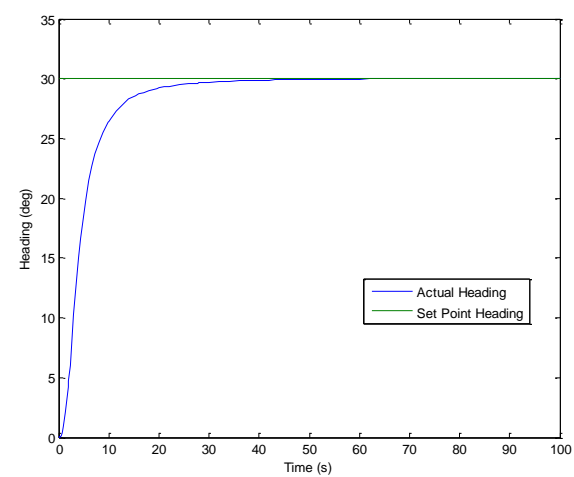

Figure $5.30^{\circ}$ set point tracking response
1. Fuzzy logic controller build for LCT Bintang Samudra maneuvering success to track desired heading at naval transportation routes in Madura strait and surroundings permitted by Naval Navigation District utilizing AIS data as its input.

2. At ship collision avoidance test, both ships route crossed each other at $t=114 \mathrm{~s}$. Ships 1 succesfully avoid collision by changing its yaw heading and velocity. Distance between both of ships at that point is $166 \mathrm{~m}$, DeltaX is $-2 \mathrm{~m}$, and velocity ratio 6.67. Ship 1 turned down its velocity from $6 \mathrm{~m} / \mathrm{s}$ to $3 \mathrm{~m} / \mathrm{s}$ and changed desired heading from $-9^{\circ}$ to $5^{\circ}$ to avoid collision.

3. Wind disturbance changed initial actual heading yaw as big as $0.352,0.334$, and 0.171 degree when initial wind angle assumed $30^{\circ}, 90^{\circ}$, and $150^{\circ}$ respectively.

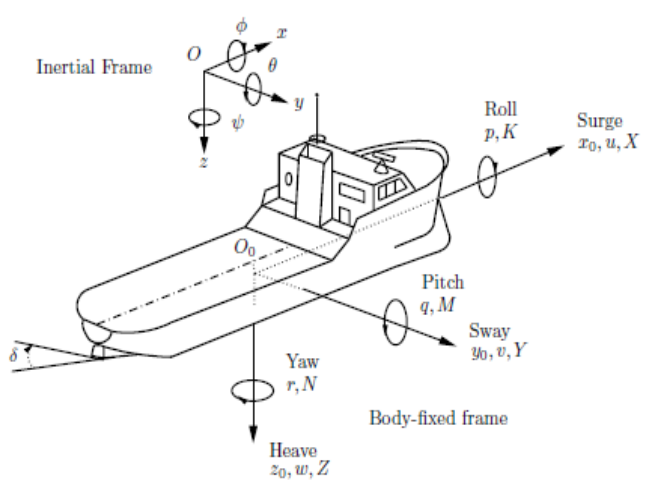

Figure 2. Ships with 6 degree of freedom (dof)

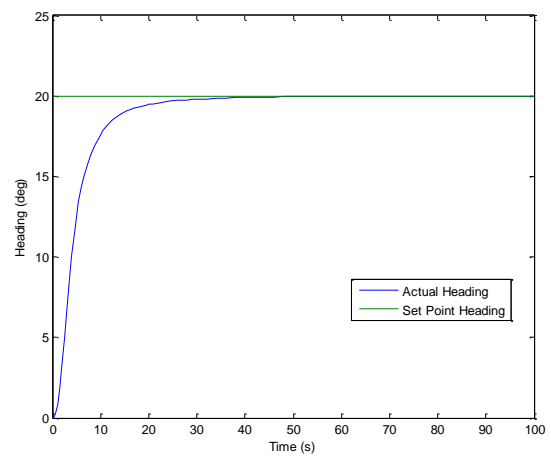

Figure $4.20^{\circ}$ set point tracking response

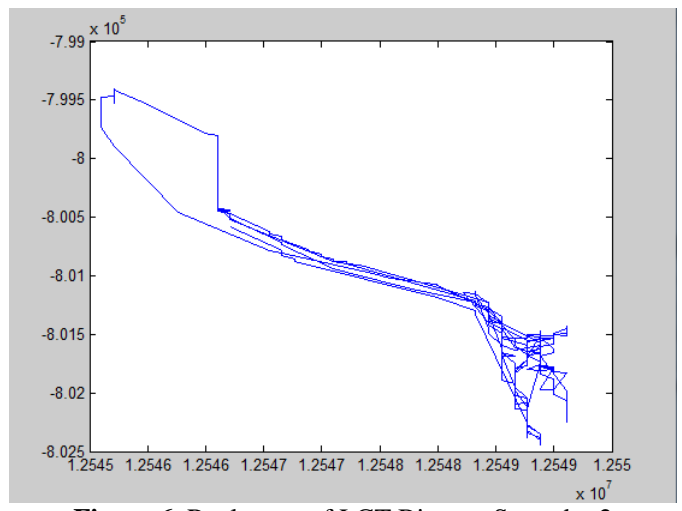

Figure 6. Real route of LCT Bintang Samudra 2 


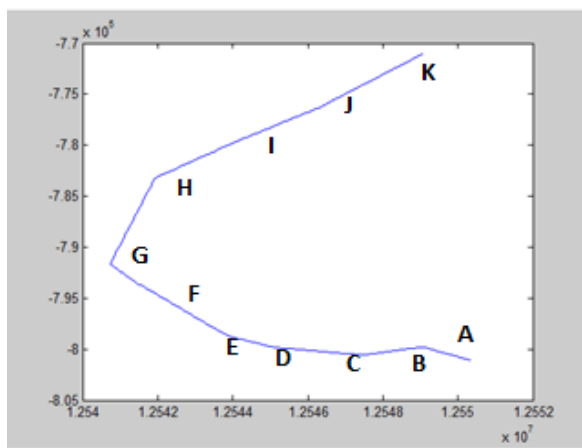

Figure 7. Karang Jamuang -Tanjung Perak naval route

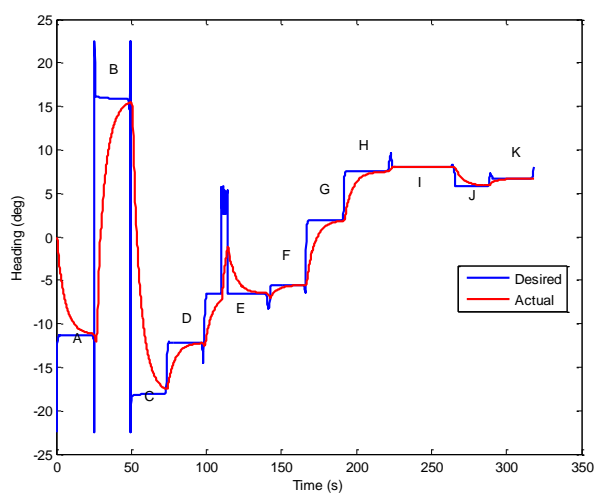

Figure 9. Closed loop response with obstacle and without wind disturbance

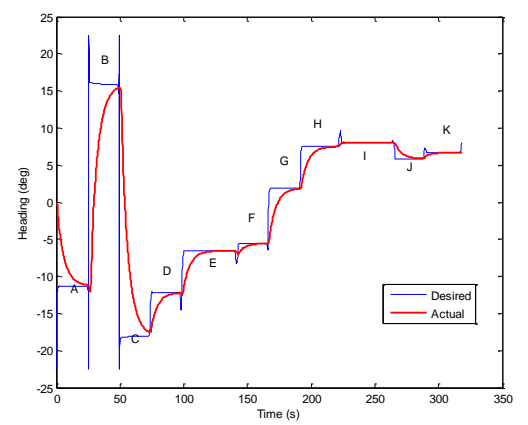

Figure 8. Closed loop response without obstacle and wind disturbance

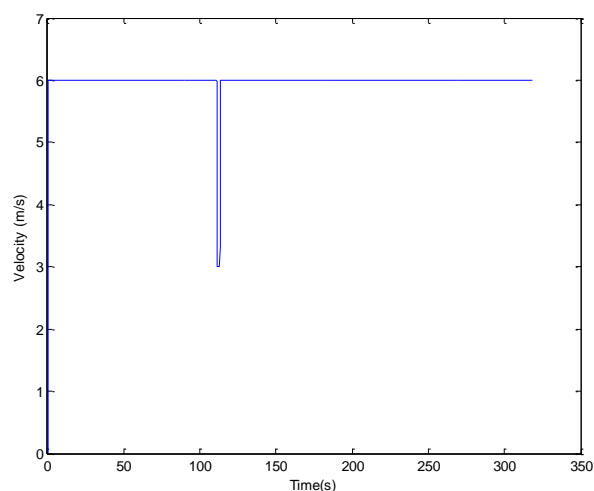

Figure 10 . Ship velocity response with other ship as obstacle

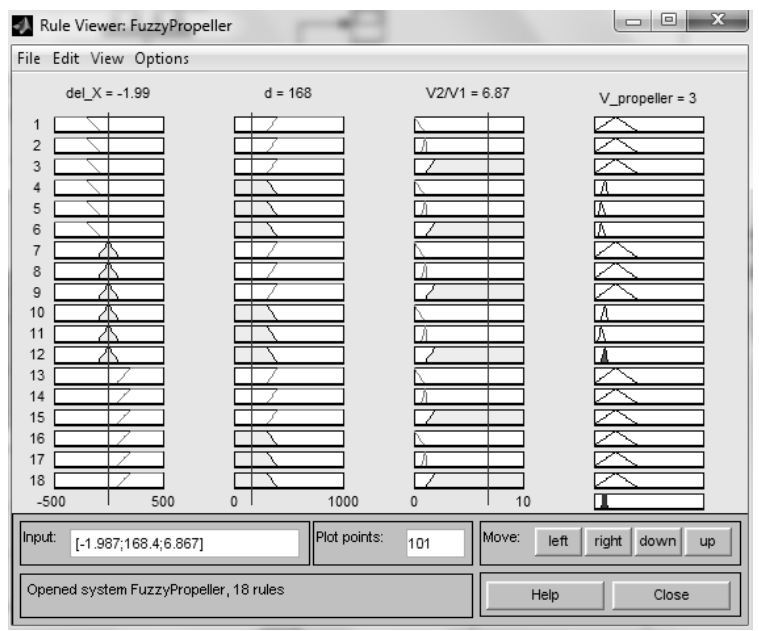

Figure 11. Ship velocity response with other ship as obstacle 
TABLE 1.

INPUT-OUTPUT RELATION OF FUZZY LOGIC CONTROLLER

\begin{tabular}{cc}
\hline Input & Output \\
\hline Error Yaw $(\psi)$ & Rudder Command \\
Yaw rate $(\mathrm{d} \psi / \mathrm{dt})$ & $\left(\delta_{R}\right)$ \\
DeltaX $(\mathrm{X})$ & \\
Distance $(\mathrm{d})$ & Propeller Voltage $(\mathrm{V})$ \\
\hline Velocity ratio $(\mathrm{V} 2 / \mathrm{V} 1)$ & \\
\hline
\end{tabular}

TABLE 2.

DESCRIPTION OF WIND

\begin{tabular}{clc}
\hline $\begin{array}{c}\text { eaufort } \\
\text { Number }\end{array}$ & $\begin{array}{c}\text { Description of } \\
\text { Wind }\end{array}$ & Wind Speed (knots) \\
\hline 0 & Calm & $0-1$ \\
1 & Light air & $2-3$ \\
2 & Light breeze & $4-7$ \\
3 & Gentle breeze & $8-11$ \\
4 & Moderate breeze & $12-16$ \\
5 & Fresh breeze & $17-21$ \\
6 & Strong breeze & $22-27$ \\
7 & Moderate gale & $28-33$ \\
8 & Fresh gale & $34-40$ \\
9 & Strong gale & $41-48$ \\
10 & Whole gale & $49-56$ \\
11 & Storm & $57-65$ \\
12 & Hurricane & more than 65 \\
\hline
\end{tabular}

TABLE 3.

\begin{tabular}{|c|c|c|c|c|}
\hline $\begin{array}{c}\text { Description } \\
\text { of Wind }\end{array}$ & $\begin{array}{l}\text { Wind } \\
\text { Speed } \\
\text { (Knots) }\end{array}$ & $\begin{array}{c}\text { Heading } \\
\text { Deviation - } \\
30^{\circ}(\mathrm{deg})\end{array}$ & $\begin{array}{c}\text { Heading } \\
\text { Deviation - } \\
90^{\circ}(\mathrm{deg})\end{array}$ & $\begin{array}{c}\text { Heading } \\
\text { Deviation - } \\
150^{\circ}(\mathrm{deg})\end{array}$ \\
\hline Calm & 1 & 0.000391 & 0.000383 & 0.000190 \\
\hline Light air & 3 & 0.003520 & 0.003447 & 0.001718 \\
\hline Light & 7 & & & \\
\hline breeze & & 0.019169 & 0.018769 & 0.009356 \\
\hline $\begin{array}{l}\text { Gentle } \\
\text { breeze }\end{array}$ & 11 & 0.047336 & 0.046350 & 0.023104 \\
\hline Moderate & 16 & & & \\
\hline breeze & & 0.100149 & 0.098063 & 0.048882 \\
\hline $\begin{array}{l}\text { Fresh } \\
\text { breeze }\end{array}$ & 21 & 0.172523 & 0.168929 & 0.084207 \\
\hline Strong & 27 & & & \\
\hline $\begin{array}{l}\text { breeze } \\
\text { Moderate }\end{array}$ & & 0.285192 & 0.279255 & 0.139200 \\
\hline $\begin{array}{l}\text { Moderate } \\
\text { gale }\end{array}$ & 33 & 0.426027 & 0.417152 & 0.207942 \\
\hline Fresh gale & 40 & 0.625936 & 0.612895 & 0.305516 \\
\hline Strong gale & 48 & 0.901347 & 0.882569 & 0.439943 \\
\hline Whole gale & 56 & 1.226834 & 1.201275 & 0.598812 \\
\hline Storm & 65 & 1.652862 & 1.618427 & 0.806754 \\
\hline Hurricane & $\begin{array}{c}\text { more } \\
\text { than } \\
65\end{array}$ & $\begin{array}{c}\text { more } \\
\text { than } \\
1.652862\end{array}$ & $\begin{array}{c}\text { more } \\
\text { than } \\
1.618427\end{array}$ & $\begin{array}{c}\text { more } \\
\text { than } \\
0.806754\end{array}$ \\
\hline
\end{tabular}

\section{REFERENCES}

[1] A. S. Aisjah, "Pengembangan Sistem Monitoring dan Kontrol Cerdas pada Kapal Untuk Peningkatan Kualitas Manajemen transportasi Laut", 2010.

[2] A. D. Shtay and W. Gharib "An Inteligent Control System for Ship Collision Avoidance" King Saud University, Kingdom of Saudi Arabia

[3] O. N. Hillali, "Pengembangan Sistem MCST (Monitoring and Control in Sea Transport) pada Kondisi Kepadatan Lalu Lintas Pelayaran di Alur Barat Tanjung Perak" Institut Teknologi Sepuluh Nopember, Surabaya, 2011

[4] Wikipedia, the free encyclopedia, February 2012. <URL:http://en.wikipedia.org/wiki/Automatic_Identification_Sy stem>1

[5] Australian Maritime Safety Autority "Auto Identification System (AIS)"

[6] Tran.T, Harris C.J, Wilson P.A "Maritime Avoidance Navigation System (MANTIS)" Department of Electronics and Computes Science, Southampton University.

[7] C. N. Hwang, J. M. Yang, and C. Y. Chiang “ The Design of Fuzzy Collision-Avoidance Expert System Implemented by $\boldsymbol{H}_{\sim}$ Autopilot".
[8] M. Lundkvist, L. Jakobsson, and R. Modigh, "Automatic Identification System (AIS) and Risk-Based Planning of Hydrographic Surveys in Swedish Waters", Sweden.

[9] H. M. Perez, R. Chang, and R. Billings "Automatic Identification System (AIS) Data Use in Marine Vessel Emission Estimation" Eastern Research Group, Inc.

[10] K.J. Rawson and E.C. Tupper "Basic Ship Teory".

[11] A.S. White, P.T. Gleeson, M. Karamanoglu "Control of Ship Capsize in Stern Quartering Seas" Middlesex University, London.

[12] Thor I. Fossen "Guidance and Control of Ocean Vehicles"

[13] K.J.Astrom and C.G.Kallstrom, "Identification of Ship Steering Dynamics'.

[14] R. Antonic, A. Cibilic, I. Golub, Z. Kulenovic, and V. Tomas "Impact of the Environmental Sea Condition to Ships Propulsion Engine Dynamics" Faculty of Maritime Studies Rijeka, Croatia.

[15] T. Perez and M. Blanke "Mathematical Ship Modeling for Control Applications" University of Newcastle, Australia

[16] Saiko, "Perancangan Sistem Pengendalian Pada Kapal Berbasis Data AIS (Automatic Identification System) Untuk Menghindari Tabrakan” Institut Teknologi Sepuluh Nopember, Surabaya, 2011 